\title{
How Destination Image Factors Affect Domestic Tourists Revisit Intention to Ba Ria-Vung Tau Province, Vietnam
}

\author{
Ha Nam Khanh GIAO ${ }^{1}$, Nguyen Thi Kim NGAN² Nguyen Pham Hanh PHUC $^{3}$, Huynh Quoc TUAN 4 , \\ Ha Kim HONG 5 , Huynh Diep Tram ANH ${ }^{6}$, Duong Thi Huynh NHU ${ }^{7}$ Ngo Thi LAN ${ }^{8}$
}

Received: April 09, 2020 Revised: April 17, 2020 Accepted: May 07, 2020

\begin{abstract}
This research examines the affect of destination image factors on revisit intention of domestic tourists at Ba Ria Vung-Tau (BRVT), by questioning directly 510 domestic tourists. The convenient sampling method is used in dividing the crowds into four groups; the four main surveyed areas in BRVT are: Vung Tau, Long Hai-Phuoc Hai, Xuyen Moc and Con Dao. A combination of qualitative and quantitative methodologies were utilized. A focus group of 10 domestic tourists was set up to review and explore the various factors as well as the conceptual model. An in-depth interview with 12 participants was developed to fine-tune measurement items. The questionnaire applied a 5-point Likert scale. Checking the reliability by Cronbach's Alpha, exploratory factor analyzing and linear multiple regression were used with the SPSS program. The results show that there are eight main destination image factors affecting domestic tourists revisit intention to BRVT using linear regression and arranged by decreasing importance: Infrastructure, Variety Seeking, Accessibility, Local food, Atmosphere, Environment, Price Value, Leisure and Entertainment. From that, the research offers some suggestions and policy recommendations for the tourism business and provincial policy-makers to identify the main issues and develop better customer services to increase domestic tourists' revisit intention.
\end{abstract}

Keywords: Destination Image, Revisit Intention, Domestic Tourists, Ba Ria-Vung Tau Province.

JEL Classification Code: C12, C83, L83, Z32

\section{Introduction}

${ }^{1}$ First Author and Corresponding Author. Dean, Faculty of Air Transport, Vietnam Aviation Academy, Vietnam [Postal Address: A65 Nam Thong 1 Town, Phu My Hung Zone, Tan Phu Ward, District 7, Ho Chi Minh City, 729000, Vietnam]

Email:khanhgiaohn@yahoo.com

'Lecturer, Faculty of Air Transport, Vietnam Aviation Academy, Vietnam. Email: kimnganhn2517@gmail.com

${ }^{3}$ Lecturer, Faculty of Tourism and Hospitality, University of Finance Marketing, Vietnam. Email: phucnguyenufm@gmail.com.

${ }^{4}$ Lecturer, Faculty of Business Administration, Dong Thap University, Vietnam. Email: hqtuan87@gmail.com

${ }^{5}$ Lecturer, Faculty of Tourism and Hospitality, University of Finance Marketing, Vietnam. Email: hakimhong810@gmail.com

${ }^{6}$ Lecturer, Faculty of Air Transport, Vietnam Aviation Academy,

Vietnam. Email: huynhdieptramanh@yahoo.com

7Staff, Department of Facilities Administration, An Giang University, Vietnam. Email: duongnhu9999@gmail.com

${ }^{8}$ Lecturer, Faculty of Business Administration, Saigon University,

Vietnam. Email: lan.tngo.sgu@gmail.com

(C) Copyright: The Author(s)

This is an Open Access article distributed under the terms of the Creative Commons Attribution Non-Commercial License (http://Creativecommons.org/licenses/by-nc/4.0/) which permits unrestricted noncommercial use, distribution, and reproduction in any medium, provided the original work is properly cited.
According to the project "Developing sea, island and coastal areas of Vietnam until 2020" by the Ministry of Culture, Sports and Tourism (MCST) on August 18th 2013, the target until 2020 is to make sea tourism become the driving force of Vietnam's marine economy; it is one of the most developed sea tourism destinations in the region. Ba Ria-Vung Tau (BRVT) is implementing solutions to focus on investment in tourism development with key forms of tourism such as forest, sea, and island tourism, as well as historical tours related to the Revolution, and resorts. By 2020, BRVT will become one of the major tourist centers of the country. BRVT is an attractive beach destination with more than 305 kilometers of coastline, including many beautiful and safe beaches. Geography and climate have given BRVT many advantages in terms of tourism: location in the most dynamic economic region of Vietnam that offers many advantages in attracting domestic tourists; many hours of sunshine during the year; relatively stable air temperature; no winters and few storms. The historical and cultural relics of BRVT are diverse, and folk festivals bearing the traditional culture of coastal people have been maintained and developed into cultural festivals. In addition, an integrated traffic system and increasingly modern connections with the neighboring provinces and cities 
provide BRVT with very favorable conditions for domestic tourists to visit and relax. In 2018, BRVT welcomed and served over 13.5 million tourists, while in the first six months in 2019 it welcomed 8.46 million tourists. Some domestic and foreign studies show that destination image is one of the factors influencing visitor behavior. Therefore, enhancing the image of tourist destinations for domestic visitors at BRVT plays an important role in guiding their loyal behavior is to increase the revisit intention.

\section{Literature Review}

\subsection{The Concept of Tourism}

According to Medlik and Middleton (1973), tourism products are the overall experience from the time people leave their homes until they return. Vietnam Tourism Law: "The tourism product is the set of services needed to satisfy the needs of tourists during the trip." According to the United Nations World Tourism Organization, tourists include: international tourist, internal tourist, domestic tourist, and national tourist, in which domestic tourists include internal tourists and international tourists. That concepts also can be found in Giao and Binh (2011, 2014), Giao and Son (2014), Giao, Binh and Tung (2014), and Giao, Hoan, Dung, Vinh and Anh (2014).

There are many studies on services and consumer behavior (Giao, 2004, 2018a, 2018b, 2018c, 2018d, 2019a, 2019b, 2020; Giao, Hoai \& Vinh, 2019, Giao, Vuong \& Quan, 2019; Vuong \& Giao, 2019; Giao, Trung \& Truong, 2019), on tourism and hospitality (Giao \& Hao, 2011; Giao \& Son, 2012; Giao, Kiem, Son \& Dung, 2018; Giao \& Son, 2018; Son \& Giao, 2018), and on destination (Giao \& Sang, 2018; Huyen \& Binh, 2020; Truong, 2020). According to Rubies (2001), a travel destination is a geographic area, which contains resources for tourism, attractions, infrastructure, equipment, service providers, other support and management organizations interacting with each other to provide visitors with the experience they expect at the destination they have chosen. According to Ha Nam Khanh Giao (2011), a destination for tourism is a point that we can perceive through geographic boundaries, politics or economy, and a place where tourism resources are attractive, capable of attracting and satisfying the needs of tourists.

Destination image (DI) has been one of the major areas in tourism's scholarly inquiry for more than four decades (Svetlana \& Juline, 2010). DI is defined as the totality of beliefs, impressions, opinions and expectations a tourist has about a destination (Crompton, 1979). DI is a totality of impressions, beliefs, ideals, expectations and feelings accumulated towards a place over time (Kim \& Richardson, 2003). Beerli and Martin (2004) have developed a system of nine components that make up DI: (1) destination attraction;
(2) recreation and entertainment; (3) natural environment; (4) overall infrastructure; (5) Culture, history and art; (6) social environment; (7) tourism infrastructure; (8) Political and economic factors; and (9) the destination's atmosphere.

\subsection{Destination Image and Tourists Revisit Intention}

According to Williams and Buswell (2003), tourist behavior can be divided into three stages: pre-, during- and post- visitation. More specifically, tourist behavior is an aggregate term, which includes pre-visit's decision-making, on-site experience, experience evaluations and post-visit's behavioral intentions and behaviors. Future behavioral intentions include the revisit intention and positive word-ofmouth. Destination image had been one of the most popular research topics in the tourism academic literature (Pike \& Page, 2014). According to Kim (2014), destination image was a favorable image of a destination formed by a combination of destination attributes (e.g., beautiful landscape, shopping opportunities, cultural exchange, infrastructure, safety, and activities). Phau, Quintal and Shanka (2014) and Huang and Hsu (2009) indicated that destination image was an important factor attracting an individual to visit and motivate revisit.

DI researchers find that the more positive the destinations, the more likely they are to be in the decision-making process. In addition, DI experiences have a positive effect on quality of perception and satisfaction. The more favorable images will lead to higher visitor satisfaction (Echtner \& Ritchie, 2003). Castro, Martin and Martin (2007) studied behavioral aspects, and found that DI had a direct positive effect on the behavioral tendency of revisit tourists. Loureiro and Gonzalez (2008) affirmed that the components of image, quality of feeling, satisfaction, and honesty were interrelated; DI directly influenced visitor loyalty. Finally, Lee (2009) finds that DI has a direct and indirect impact on the behavior of tourists in the future. Chen and Tsai (2007) proposed a behavioral model that combines the elements of DI and perceived value, satisfaction, and behavioral tendencies. In this study, the factors that belonged to DI were identified: Destination brand; Entertainment; Nature and culture; and Weather and beaches. The behavior of visitors is indicated by the revisit intention for next time or the willingness to introduce another person to this destination.

Chi and Qu (2008) provided the loyalty model for the destination as follows: (i) DI directly influences the attributes of satisfaction; (ii) DI and the attribute of satisfaction converge toward total satisfaction; (iii) The overall satisfaction and the attribute of satisfaction strongly and positively affect the loyalty of visitors. DI consists of nine factors: Travel environment; Natural Attractions; Entertainment and events; Historic attractions; Travel infrastructure; Accessibility; Relaxation, Outdoor activities and Price and value. Perceived factors consists of seven 
factors: Lodging; Dining; Shopping; Attractions; Activities and Events, Environment and Accessibility. Destination loyalty consists of Revisit intention and Referral intention.

A study by Park and Nunkoo (2013) investigates the effects of DI factors (including seven factors) on the overall DI. This model also determines that overall DI has a positive effect on visitor loyalty. Loyalty mentioned in the model is understood as the revisit intention of visitors or intention to introduce others. The study by Tuu and Cam (2012) examined the indirect effects of DI factors such as the Environment; Cultural and community; Cuisine; Entertainment; Facilities; and Trends, seeking to differentiate visitors based on the revisit intention and positive word-of-mouth for international visitors to Nha Trang through the intermediary variable of satisfaction. The study of Vietnam DI impact on the revisit intention of international tourists by Nhu et al. (2013) showed that DI is the most important factor in the revisit intention of tourists. The more promising DI, the more positive the revisit intention of visitors. Six factors that make up Vietnam DI are: Attractive features of culture; Cuisine; Natural environment; Travel infrastructure; Socio-economic environment; Natural resources and language; and Atmosphere of the destination.

Based on the synthesis of previous studies, a research gap in the direct relationship between DI components and behaviors and loyalty is identified. In order to clarify this relationship, some intermediate variables will not be considered; this study will only focus on the direct relationship between the critical components of DI and the loyalty approached on the loyal behavioral concept. This research builds on the conceptualization and scale of Giao, Phuc and Ngan (2018) and proposes the research model(see Figure 1) and hypotheses as below.

\section{Research Results}

\subsection{Sample Description Statistics}

The convenient sampling method is used to divide the tourist population into four groups, corresponding to the four main surveyed areas in BRVT: Vung Tau, Long Hai- Phuoc Hai, Xuyen Moc and Con Dao, which are the areas where most domestic tourists usually come. The survey is conducted among the domestic tourists who have visited BRVT in the last quarter of 2019. 550 questionnaires were distributed, 525 valid forms were collected, 15 were invalid, finally collected 510/450 (93\%), which was satisfactory. The research was conducted on 398 observations that required domestic tourists in BRVT to stay over 24 hours and stay overnight there. The characteristics of the samples are detailed in Table 1.

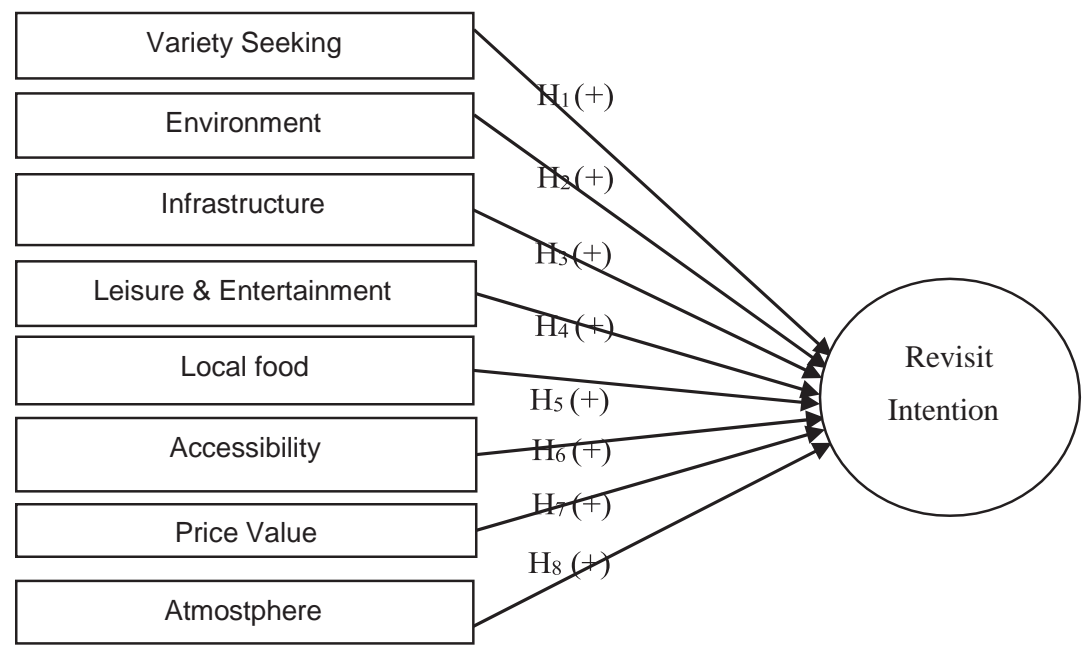

Figure 1: The proposed research model

Hypothesis H1: The Variety Seeking (Variety Seeking - VS) affects the revisit intention (RI) of visitors positively.

Hypothesis H2: The Environment (Environment - ENV) affects the revisit intention of visitors positively.

Hypothesis H3: The Infrastructure (Infrastructure - INF) affects the revisit intention of visitors positively.

Hypothesis H4: The Leisure \& Entertainment (Leisure \& Entertainment-LE) affects the revisit intention of visitors positively.

Hypothesis H5: The Local food (Local food - LF) affects the revisit intention of visitors positively.

Hypothesis H6: The Accessibility (Accessibility - AC) affects the revisit intention of visitors positively.

Hypothesis H7: The Price Value (Price Value - PV) affects the revisit intention of visitors positively.

Hypothesis H8: The Atmosphere (Atmosphere - AMP) affects the revisit intention of visitors positively. 
Table 1: Summary of survey sample characteristics

\begin{tabular}{|c|c|c|c|}
\hline \multicolumn{2}{|c|}{ Characteristics of the sample (sample size $n=510$ ) } & Quantity (people) & Ratio (\%) \\
\hline \multirow[t]{2}{*}{ Genders } & Male & 201 & 39.41 \\
\hline & Female & 309 & 60.59 \\
\hline \multirow[t]{5}{*}{ Ages } & $15-24$ & 63 & 12.35 \\
\hline & $25-34$ & 210 & 41.18 \\
\hline & $35-44$ & 117 & 22.94 \\
\hline & $45-54$ & 65 & 10.78 \\
\hline & Over 54 & 55 & 4.27 \\
\hline \multirow[t]{4}{*}{ Income } & Under 4 mil. VND & 57 & 11.18 \\
\hline & 4 to under 7 mil. VND & 113 & 22.16 \\
\hline & 7 to under 15 mil. VND & 279 & 54.71 \\
\hline & Over 15 mil. VND & 61 & 11.96 \\
\hline \multirow[t]{4}{*}{ Education } & School & 57 & 19.60 \\
\hline & Vocational college & 103 & 20.20 \\
\hline & College, University & 331 & 64.90 \\
\hline & Post-graduate & 19 & 3.73 \\
\hline \multirow[t]{4}{*}{ Place surveyed } & Vung Tau & 219 & 42.94 \\
\hline & Xuyen Moc & 75 & 14.71 \\
\hline & Long Hai - Phuoc Hai & 114 & 22.35 \\
\hline & Con Dao & 72 & 14.12 \\
\hline \multirow[t]{7}{*}{ Regions } & Red river delta & 62 & 12.16 \\
\hline & North Central & 37 & 7.25 \\
\hline & South Central & 58 & 14.57 \\
\hline & Highlands & 53 & 10.39 \\
\hline & South East & 167 & 32.75 \\
\hline & South West & 133 & 26.08 \\
\hline & Total & 510 & 100.00 \\
\hline
\end{tabular}

Table 2: Cronbach's Alpha results of scales

\begin{tabular}{|c|l|c|c|c|c|}
\hline No. & \multicolumn{1}{|c|}{ Scales } & Symbols & $\begin{array}{c}\text { Number of } \\
\text { observed variables }\end{array}$ & $\begin{array}{c}\text { Cronbach's } \\
\text { Alpha Coefficient }\end{array}$ & $\begin{array}{c}\text { Smallest Item-total } \\
\text { correlation }\end{array}$ \\
\hline 1 & Variety seeking & VS & 4 & 0.832 & 0.555 \\
\hline 2 & Environment & ENV & 6 & 0.832 & 0.360 \\
\hline 3 & Infrastructure & INF & 4 & 0.794 & 0.597 \\
\hline 4 & Leisure and Entertainments & LE & 5 & 0.803 & 0.383 \\
\hline 5 & Local food & LF & 4 & 0.675 & 0.360 \\
\hline 6 & Accessibility & AC & 5 & 0.839 & 0.547 \\
\hline 7 & Price value & PV & 7 & 0.796 & 0.594 \\
\hline 8 & Atmosphere & AMP & 5 & 0.853 & 0.483 \\
\hline 9 & Revisit intention & RI & 3 & 0.625 & 0.460 \\
\hline
\end{tabular}

\subsection{Verification of the Scale}

Scales were measured through two tools, which were Cronbach's Alpha reliability coefficient and EFA. Table 2 showed that all scales had Cronbach's Alpha reliability of 0.6 and a total correlation coefficient of over 0.3 (Giao \& Vuong, 2019). Thus, all observation variables of the scales satisfied conditions for EFA.

The EFA method was used for 40 independent variables, using Principal Component method with Varimax rotation and the stoppage when extracting elements with Eigenvalues of 1 . The result of EFA analysis for $\mathrm{KMO}=0.801$ was satisfactory which was greater than 0.5 , explaining the appropriate sample size for factor analysis and Barlett coefficient of Sig $=0.000<0.5$ (with correlation between variables) confirmed that the analysis method above was appropriate, average variance extracted $75.950 \%$ and the factor loadings are greater than 0.5 , which was satisfactory (see Table 3). 
Ha Nam Khanh GIAO, Nguyen Thi Kim NGAN, Nguyen Pham Hanh PHUC, Huynh Quoc TUAN, Ha Kim HONG, Huynh Diep Tram ANH, Duong Thi Huynh NHU7, Ngo Thi LAN / Journal of Asian Finance, Economics and Business Vol 7 No 6 (2020) 209 - 220

Table 3: EFA results for independent variables

\begin{tabular}{|c|c|c|c|c|c|c|c|c|}
\hline \multirow{2}{*}{$\begin{array}{l}\text { Observed } \\
\text { variables }\end{array}$} & \multicolumn{8}{|c|}{ FACTOR LOADING } \\
\hline & 1 & 2 & 3 & 4 & 5 & 6 & 7 & 8 \\
\hline $\mathrm{EN}_{5}$ & 0.786 & & & & & & & \\
\hline $\mathrm{EN}_{4}$ & 0.719 & & & & & & & \\
\hline $\mathrm{EN}_{1}$ & 0.718 & & & & & & & \\
\hline $\mathrm{EN}_{2}$ & 0.712 & & & & & & & \\
\hline $\mathrm{EN}_{3}$ & 0.690 & & & & & & & \\
\hline $\mathrm{EN}_{6}$ & 0.670 & & & & & & & \\
\hline $\mathrm{AC}_{3}$ & & 0.652 & & & & & & \\
\hline $\mathrm{AC}_{2}$ & & 0.780 & & & & & & \\
\hline $\mathrm{AC}_{1}$ & & 0.746 & & & & & & \\
\hline $\mathrm{AC}_{4}$ & & 0.739 & & & & & & \\
\hline $\mathrm{AC}_{5}$ & & 0.731 & & & & & & \\
\hline $\mathrm{PV}_{4}$ & & & 0.750 & & & & & \\
\hline $\mathrm{PV}_{2}$ & & & 0.894 & & & & & \\
\hline $\mathrm{PV}_{6}$ & & & 0.825 & & & & & \\
\hline $\mathrm{PV}_{7}$ & & & 0.804 & & & & & \\
\hline $\mathrm{PV}_{3}$ & & & 0.841 & & & & & \\
\hline $\mathrm{PV}_{5}$ & & & 0.818 & & & & & \\
\hline $\mathrm{PV}_{1}$ & & & 0.605 & & & & & \\
\hline $\mathrm{LE}_{3}$ & & & & 0.772 & & & & \\
\hline $\mathrm{LE}_{2}$ & & & & 0.748 & & & & \\
\hline $\mathrm{LE}_{1}$ & & & & 0.742 & & & & \\
\hline $\mathrm{LE}_{4}$ & & & & 0.737 & & & & \\
\hline $\mathrm{LE}_{5}$ & & & & 0.696 & & & & \\
\hline $\mathrm{INF}_{3}$ & & & & & 0.820 & & & \\
\hline $\mathrm{INF}_{2}$ & & & & & 0.803 & & & \\
\hline $\mathrm{INF}_{1}$ & & & & & 0.705 & & & \\
\hline $\mathrm{INF}_{4}$ & & & & & 0.682 & & & \\
\hline $\mathrm{AMP}_{5}$ & & & & & & 0.843 & & \\
\hline $\mathrm{AMP}_{1}$ & & & & & & 0.841 & & \\
\hline $\mathrm{AMP}_{2}$ & & & & & & 0.790 & & \\
\hline $\mathrm{AMP}_{4}$ & & & & & & 0.732 & & \\
\hline $\mathrm{AMP}_{3}$ & & & & & & 0.658 & & \\
\hline $\mathrm{LF}_{2}$ & & & & & & & 0.771 & \\
\hline $\mathrm{LF}_{3}$ & & & & & & & 0.716 & \\
\hline $\mathrm{LF}_{1}$ & & & & & & & 0.641 & \\
\hline $\mathrm{LF}_{4}$ & & & & & & & 0.593 & \\
\hline $\mathrm{VS}_{3}$ & & & & & & & & 0.829 \\
\hline $\mathrm{VS}_{2}$ & & & & & & & & 0.744 \\
\hline $\mathrm{VS}_{1}$ & & & & & & & & 0.650 \\
\hline $\mathrm{VS}_{4}$ & & & & & & & & 0.641 \\
\hline
\end{tabular}


Results of exploratory factor analysis for dependent variable "Revisit intention" with 3 observed variables show that coefficient $\mathrm{KMO}=0.848$, and Barlett coefficient with Sig. $=0.000<0.5$, average variance extracted $67.950 \%$, and variables have factor loading which is greater than 0.5 . Thus, the factor of revisit intention to BRVT of tourists consists of three variables (Giao \& Vuong, 2019).

\subsection{Correlation Analysis}

To examine the linear correlation between independent variables and dependent variables, Pearson correlation coefficients were used. Table 4 shows that there is a linear relationship between the scales, between the dependent variable and all independent variables (no $\mathrm{r}=0$ ), in which, the Environmental Scale has the highest correlation $r=0.620$

\subsection{Multiple Linear Regression Analysis}

From Table 5, the ANOVA results showed the F statistic of the model $=90.525$ with a significance level of $1 \%$ ( $\mathrm{sig}$ $=0.000$ ), indicating that the linear regression model was consistent with the data and that independent variables that had linear relationship with dependent variable and so model can be used. The adjusted coefficient of $\mathrm{R}^{2}$ is 0.565 , or $56.5 \%$ of the variance of domestic tourists revisit intention

Table 4: Pearson's correlation coefficient matrix

\begin{tabular}{|c|c|c|c|c|c|c|c|c|c|c|}
\hline & & RI & vs & ENV & INF & LE & LF & AC & PV & AMP \\
\hline $\mathrm{RI}$ & Pearson & 1 & $0.045^{*}$ & $0.620^{* *}$ & $0.422^{* *}$ & $0.283^{* *}$ & $0.272^{* *}$ & $0.465^{*}$ & $0.369^{* *}$ & $0.421^{* *}$ \\
\hline VS & Pearson & $0.045^{*}$ & 1 & $0.098^{*}$ & $0.109^{*}$ & $0.118^{*}$ & $0.059^{*}$ & $0.025^{*}$ & $0.020^{*}$ & $0.041^{*}$ \\
\hline ENV & Pearson & $0.620^{* *}$ & $0.098^{*}$ & 1 & $0.203^{* *}$ & $0.082^{*}$ & $0.232^{* *}$ & $0.291^{* *}$ & $0.153^{* *}$ & $0.329^{* *}$ \\
\hline INF & Pearson & $0.422^{* *}$ & $0.109^{*}$ & $0.203^{* *}$ & 1 & $0.036^{*}$ & $0.116^{*}$ & $0.236^{* *}$ & $0.128^{*}$ & $0.147^{* *}$ \\
\hline LE & Pearson & $0.283^{* *}$ & $0.118^{*}$ & 0.082 & 0.036 & 1 & $0.017^{*}$ & 0.083 & $0.140^{* *}$ & $0.114^{*}$ \\
\hline LF & Pearson & $0.272^{* *}$ & $0.059^{*}$ & $0.232^{* *}$ & $0.116^{*}$ & 0.017 & 1 & $0.209^{* *}$ & $0.097^{*}$ & $0.144^{* *}$ \\
\hline$A C$ & Pearson & $0.465^{* *}$ & $0.025^{*}$ & $0.291^{* *}$ & 0.236 & 0.083 & $0.209^{* *}$ & 1 & $0.150^{* *}$ & $0.124^{* *}$ \\
\hline $\mathrm{PV}$ & Pearson & $0.369^{* *}$ & $0.020^{*}$ & $0.153^{* *}$ & $0.128^{*}$ & $0.140^{* *}$ & $0.097^{*}$ & $0.150^{* *}$ & 1 & $0.232^{* *}$ \\
\hline $\mathrm{RI}$ & Pearson & $0.42^{* *}$ & $0.041^{*}$ & $0.329^{* *}$ & $0.147^{* *}$ & $0.114^{*}$ & $0.144^{* *}$ & $0.124^{* *}$ & $0.232^{* *}$ & 1 \\
\hline \multicolumn{11}{|c|}{ **. Significant correlation at $1 \%$ (2-way test). } \\
\hline & De somolo & at $5 \%$ & ay test). & & & & & & & \\
\hline
\end{tabular}

Table 5: Regression results

\begin{tabular}{|c|c|c|c|c|c|c|}
\hline \multirow{2}{*}{ Models } & \multicolumn{2}{|c|}{ Unstandardized coefficient } & \multirow{2}{*}{$\frac{\text { Standardized coefficient }}{\text { Beta }}$} & \multirow{2}{*}{$\begin{array}{l}\text { Level of } \\
\text { significance }\end{array}$} & \multicolumn{2}{|c|}{ Multicollinearity } \\
\hline & B & Standard error & & & Allowance & VIF \\
\hline (Constant) & 0.629 & 0.183 & & 0.001 & & \\
\hline VS & 0.353 & 0.043 & 0.228 & 0.010 & 0.750 & 1.333 \\
\hline ENV & 0.098 & 0.043 & 0.047 & 0.005 & 0.813 & 1.230 \\
\hline INF & 0.306 & 0.037 & 0.305 & 0.000 & 0.621 & 1.611 \\
\hline LE & 0.037 & 0.033 & 0.022 & 0.001 & 0.749 & 1.335 \\
\hline LF & 0.116 & 0.036 & 0.171 & 0.000 & 0.689 & 1.450 \\
\hline$A C$ & 0.185 & 0.047 & 0.176 & 0.000 & 0.613 & 1.520 \\
\hline PV & 0.053 & 0.033 & 0.042 & 0.000 & 0.791 & 1.354 \\
\hline AMP & 0.072 & 0.046 & 0.069 & 0.003 & 0.632 & 1.502 \\
\hline \multicolumn{7}{|c|}{$\begin{array}{l}\text { Adjusted } R^{2}: 0.565 \\
\text { Durbin-Watson Statistic: } 1.955 \\
\text { F Statistic (ANOVA): } 90.525 \\
\text { Level of significance (ANOVA Sig.): } 0.000\end{array}$} \\
\hline
\end{tabular}


to BRVT was explained by independent variables (Giao \& Vuong, 2019). The regression results also showed that there were six significant variables at $1 \%$ (Sig. $\leq 0.01), 1$ statistically significant at $5 \%$ (Sig. $\leq 0.05), 1$ no statistically significant change, theoretical model is consistent with the research data. The unstandardized regression equation had the form as follow:

$$
\begin{aligned}
& \mathrm{RI}=0.629+0.353 * \mathrm{VS}+0.098 * \mathrm{ENV}+0.306 * \mathrm{INF} \\
& +0.037 * \mathrm{LE}+0.116 * \mathrm{LF}+0.185 * \mathrm{AC}+0.053 * \mathrm{PV}+ \\
& 0.072 * \mathrm{AMP}
\end{aligned}
$$

In detecting violations of linear regression models, the scatterplot showed that the remainder did not change in any order for the predicted value, they dispersed randomly, and the hypothesis of the linear relationship is not violated. Spearman correlation coefficients of absolute values of residuals and independent variables: Sig value of correlation coefficients with $95 \%$ confidence intervals are greater than 0.05 , indicating that the variance of the error remained unchanged, showing no violation. The histogram showed the normal distributed residue with a mean value close to zero (Mean $=-8,75 \mathrm{E}-15)$ and its standard deviation was close to $1(\mathrm{SD}=0,995)$. The P-P plot showed the actual observation points that were quite close to the diagonal of the expected values, which meant that the residual data had a normal distribution. Coefficient $1<$ Durbin - Watson $=1,955<3$ satisfied the condition, the variance coefficient VIF $<10$ showed that the independent variables were not closely related so there was no multicollinearity. Thus, the linear regression model constructed by the above equation did not violate the regression assumptions (Giao \& Vuong, 2019).

We can conclude that the hypotheses $\mathrm{H}_{1}, \mathrm{H}_{2}, \mathrm{H}_{3}, \mathrm{H}_{4}$,

$\mathrm{H}_{5}, \mathrm{H}_{6}, \mathrm{H}_{7}, \mathrm{H}_{8}$ proposed in the original study model are acceptable, in which $\beta_{3}>\beta_{1}>\beta_{6}>\beta_{5}>\beta_{8}>\beta_{2}>\beta_{7}>\beta_{4}$. The destination image factors that affect domestic tourists revisit intention are in the descending order: $\mathrm{INF}>\mathrm{VS}>\mathrm{AC}>\mathrm{LF}$ $>\mathrm{AMP}>\mathrm{EN}>\mathrm{PV}>\mathrm{LE}$.

\subsection{Difference Testing}

The purpose of this analysis is to find differences in domestic tourists revisit intention to BRVT assessed by factors presented in Table 1. In this section, ANOVA and T-test are used to find differences in characteristics of respondents versus domestic tourists revisit intention to BRVT. The results show that there is no difference in domestic tourists revisit intention to BRVT by gender as well as education, place surveyed and regions; when it comes to difference by age and income, the older and the domestic tourists, the greater their intention to revisit BRVT.

\section{Management Implications and Conclusion}

\subsection{Management Implications}

\subsubsection{Development of Tourism Infrastructure}

This is the strongest factor affecting domestic tourists revisit intention to BRVT, and the general mean is 3.84 (out of 5 ) shows that the tourism infrastructure that meets the needs of visitors and is easy access to destinations will contribute to enhancing the destination image and increasing the revisit intention of visitors. The province should continue to improve the overall planning of tourism development associated with the region and the country, study is differentiated for reasonable planning in each period; develop Con Dao tourism plan; have detailed planning of some potential and beneficial areas of tourism development such as Vung Tau, Long HaiPhuoc Hai, Xuyen Moc and Con Dao. Develop it into many areas with great architecture, impressive, perfect services, high quality, and international standards. It is expected that some basic items of each zone include: 5-star hotels, villas, luxury resorts; standard international golf course; high-end entertainment complex with many unique and intellectual services; health rehabilitation center, medical examination and treatment; sports and entertainment center; special sightseeing vehicles (cable cars, electric vehicles, rudimentary vehicles); airport; tourist port; restaurants, and high-end bars. Promote the implementation of projects in tourist corridors along the coastline of Vung Tau - Long Hai - Phuoc Hai - Binh Chau. At the same time, withdraw all the projects, which are not able to continue for further calling on other enterprises' investment and develop this corridor into a diversified, attractive and high-quality tourist route of the province.

The province needs to develop a preferential mechanism to attract investment in tourism, form a number of key tourist areas with domestic, regional and international competitiveness, and create incentives for the tourism industry. In order to ensure the sustainable development of tourism, recommendations should be made in the selection of strategic investors to develop tourism in line with local conditions and characteristics. Strengthen state support by actively allocating state budget investment in the construction of tourist infrastructure, creating favorable conditions for tourists to access tourist sites, local tourist attractions and ancillary facilities such as trade center, high-end conference - exhibition - fair area easily. At the same time, upgrade and renovate cultural sites and parks in districts and towns with high tourism potential to improve tourism infrastructure.

\subsubsection{Variety Seeking}

The general mean of this factor is 4.005 , implying that visitors have rather high intention to comeback to BRVT to 
explore the natural landscape, and the other types of tourism. Research results reveal that tourists are extremely satisfied with favorable attributes such as "I would like to visit places and attractiveness that I never been in", "I would like to enhance my knowledge of history and development of places and human being culture". This convincingly proves that besides Vung Tau as the main place, most of domestic tourists still want to know more about the other picturesque natural landscapes such as Xuyen Moc, Ba Ria, Bình Chau, Long Son, etc, especially Con Dao where they not only enjoy the beautiful island, but also can learn of the Vietnamesefemale hero Vo Thi Sau, and of the heroic struggle of Vietnamese toward independence. Therefore, it is essential to develop these types of tourism in an intensive approach in order to promote the potential of natural and historical tourism resources in BRVT. It is also suggested to promote and train a dedicated tourism workforce. In addition, local authorities of BRVT should attach special attention to sustainable ecotourism development in order to maintain and develop the ecological strength in the locality.

In the future, BRVT should focus on community-based high-quality resort tourism and eco-tourism. The exploitation of nature discovery and resort tours, together with the use of local people as tour guides, should be effectively promoted. This is supposed to create a unique image for those who visit BRVT. In addition, it is essential to exploit the local traditional cultural values for tourism development. Aspecial focus should be made to develop cultural tourism, spiritual tourism, historical sites and archaeological relics. Adequate propaganda and advertisement campaigns should be targeted at tourists who visit BRVT to elicit their desire to have an immersive experience in the daily life of the local community, and enjoy regional specialties.

\subsubsection{Accessibility}

The general mean of this factor is 3.6, implying that tourist intention to revisit is at average level. The province should call for investment in tourist ships. Mobilizing capital budget and other sources of capital to invest in transport infrastructure (roads and passenger transport means) to improve access to tourist destinations has been planned into key tourism projects. Continue to monitor the implementation of the project after the license, remove difficulties and obstacles for investors, and support the promotion of tourism investment projects along the coastline of Vung Tau - Long Hai - Phuoc Hai - Binh Chau.

In terms of information, promotion and tourism advertising, in the coming years, specific action plans should be put in place to promote communication activities to raise awareness of society on tourism development and promotion effectiveness and to promote domestic and foreign tourism. Besides, actively organize cultural, sports and tourism events to promote BRVT tourism and attract tourists. Ensure that is convenient for tourists to travel in the province by organizing information guide, support tourists at the pier, bus station, seaport, on the means involved in transporting passengers. Develop diversification of tourism products, focusing on high-quality tourism projects, tourism products for recreation and entertainment activities, sightseeing, and shopping. Prioritize the selection of a number of land areas with advantageous and potential position so as to call on capable and experienced investors to develop large and quality tourism projects that promote the tourism industry and help visitors easily access these activities.

\subsubsection{Develop Culinary Activities}

The general mean of this factor is 3.42 , implying that tourist intention to revisit is at average level. To diversify culinary activities and provide a variety of dishes for visitors, the province needs to provide support to local communities to develop local food businesses with BRVT cultural identities to differentiate and enhance DI. Authorities should strengthen the inspection of the implementation of regulations on food safety and hygiene at catering establishments. In addition, have issuance of sanctions for violations of food safety and hygiene. The dissemination and criticism of negative behaviors in the food business such as the use of poor quality food, the lack of hygiene in food processing, etc. should be implemented regularly for food businesses to get the information and comply with regulations. All this will contribute to enhancing the destination image through culinary activities by providing visitors with dishes that are rich in local cultural identity and ensuring food safety and quality.

\subsection{Tourism Atmosphere}

The general mean of this factor is 3.45 , meaning that tourist intention to revisit is at average level. To enhance the destination image by giving visitors a free, peaceful and comfortable atmosphere, the province should take measures to give visitors the feeling of freedom by regulating and implementing sanctions for unfair competition acts such as rowing, clinging to tourists to create a free travel atmosphere for visitors. Make sure there is no begging to impress visitors on DI travel, bring comfort to visitors. Continue to control the implementation of the decision to ban all beach eating and drinking businesses. In addition, visitors are not allowed to bring alcohol or beer, do not organize drinking, waste disposal at the beach area, public places are well implemented in Vung Tau City, and should be applied to some other tourist areas of the province. This enhances DI in the heart of tourists and gives visitors a pleasant feeling when traveling at BRVT. 


\subsubsection{Tourism Environment}

The general mean of this factor is 3.48 , meaning that tourist intention to revisit is at average level. A clean environment, a safe and secure tourist spot, along with many festivals or events, attractive cultural and historical sites, natural landscapes, increasing local community involvement in tourism activities will contribute to improving the destination image and increasing the revisit intention of tourists. In order to create a tourist environment that meets the requirements of visitors, BRVT province should continue to implement the plan of restoration and renovation of historical/cultural relics, religious beliefs, etc. At the same time, regular cultural, sports and tourism events are organized to promote the tourism of BRVT and create attraction to increase the revisit intention of tourists. Carry out a project to secure a tourism environment, develop a clean strategy and action programs around this theme such as "Clean Food, Clean Beach," or "Beautiful Clean Green Resort". They are necessary to make a good impression on the tourists by creating a breakthrough for the tourism industry of the province. Ensure the security of tourism by strengthening the state management of tourism businesses. Set up minimum standards for home-stay and lodging businesses, beaches, restaurants, and hotels. Propagate and disseminate laws and regulations on tourism, mobilize all objects and classes in society to actively participate in preserving security and order, protecting the environment and protecting natural resources. It is the place where people live and work in civilized and polite ways, respecting the law, building a civilized movement and a friendly attitude towards tourists.

Businesses should develop and implement measures to improve the effectiveness of management of security in the field of tourism, study solutions to organize forces to ensure security and thoroughly solve the situation of disorder at the tourist attractions to create safety for visitors. Business facilities of sea bathing services should ensure the rescue work is done to ensure safety for tourists, minimizing the drowning situation, falling into the vortex pools, endangering the lives of visitors. Propagate and disseminate laws and regulations on tourism, mobilize all objects and classes in the society to actively participate in preserving security, protecting the environment and protecting natural resources. It is the place where people live and work in civilized and polite ways, respecting the law, building a civilized movement and a friendly attitude towards tourists. Actively involve local communities in policy-making and decision-making, capacity building, creative thinking and positive thinking to realize the ideas for the effectiveness of sustainable tourism development.

\subsubsection{Ensure a Reasonable Price for Visitors}

The general mean of this factor is 3.7 , implying that tourist intention to revisit is at average level. In order to ensure that BRVT is a cost-effective travel destination, the prices of the products and services provided are reasonable with their quality, the authorities should enhance the price stabilization of services. Specific measures such as listing prices at service businesses, the increase or decrease of prices should be strictly controlled by the authorities. In addition, the issuance of penalties for price violations to combat unfair competitive practices such as lower prices for inferior quality products, fraud, pinching, rowing and wearing stick to visitors. The propaganda, struggle and criticism of negative behaviors in tourist business activities, such as raising prices of irrational services and trade frauds should be regularly implemented so that service providers will get the information and strictly follow regulations. At the same time, praise good examples, effective business models in the tourism industry for replication and innovation.

\subsubsection{Development of Recreational Activities}

The general mean of this factor is 4.01, meaning that tourist intention to revisit is at a rather high level. Develop recreational activities by focusing on building and implementing the development plan of special tourism products in BRVT province, improving the quality of bathing services, diversification in travel forms, leisure activities and outdoor activities. In order to speed up the implementation of tourism projects, the functional agencies should focus on solving the problems of investors, supporting the development of tourism products and services, and planning to check progress of implementation of investment projects to accelerate the transfer of registered capital to implemented capital. Business facilities of sea bathing services should ensure the quality of bathing services. Rescue work must be carried out at sea bathing service providers to ensure safety for tourists, minimizing drowning and falling into vortex pools, endangering the lives of tourists.

Businesses need to have plans to build new tours, develop sea tours, visit historical sites, scenic places, sports climbing, ecotourism, craft villages travel, homestay travel, diversifying outdoor activities, nighttime entertainment as well as in conjunction with interprovincial tours to attract visitors, create the richness and distinctive brand of local tourism, extend the length of stay and expenditure of visitors to travel. At the same time, businesses need to promote and build brand, and improve competitiveness in the domestic market. Accommodation businesses should register for quality standards of service and accommodation to enhance 
the position of the businesses and at the same time contribute to improving the overall destination image.

\subsubsection{Other Management Implications}

Participation of local communities in tourism not only benefits them and the environment, but also enhances the quality of tourism. The sustainability of tourism depends greatly on the support and involvement of local communities. Specific measures to promote the participation of local communities in tourism activities have to respect the needs and aspirations of the people; facilitate local people to decide on their own development; encourage the active participation of people and tourism projects; support shops, restaurants and guides owned by local people; and restrict divisions and local immigrants.

Regarding the sustainable human resource development strategy, the province should focus on building prestigious and quality tourism training centers; organizing professional training courses for laborers of the branch in order to develop both the quantity and quality of tourism human resources to meet the development demands of the tourism industry. Determining that tourism development is really a key economic sector, the province's smoke-free industry requires the strengthening of country management in tourism in order to meet the requirements and tasks of the sector; especially, to sustain tourism development.

Strategic planning policies and central plans for tourism development must be implemented in a timely and effective manner in the province and at the same time revise and amend provincial regulations on management and distribution. Strengthening the coordination between local departments in appraising, monitoring and supervising the progress of investment projects in accordance with the development orientation of the province. Upgrade the service quality of the passenger transportation system, contributing to creating favorable conditions for tourist development, directing seaports and means to transport passengers and arranging forces to ensure environmental hygiene, security and order, friendly service attitude, organization of information guide, supporting tourists.

In the investment and tourism development, priority should be given to calling for investment in projects to accelerate the development of the sectors such as environmental improvement projects, waste water treatment, technical infrastructure, technology application, investment in the construction of large-scale tourist resorts. Increase investment in infrastructure, promote the advertisement and branding of destination images, prioritize investment in such programs as tourism infrastructure investment, human resource development programs, tourism promotion programs, marine tourism development projects, community tourism, disaster and climate response programs, and tourism development master plan. Promote the inspection and examination of tourist business forms so as to ensure that tourist activities are developed in a convenient and lawful manner and strictly handled according to the provisions of law for cases of violation, enhance the role and perform well the coordination between functional branches to enhance the effectiveness of country management in the field of tourism.

\subsection{Conclusion}

The main objective of this study is to determine the theoretical relationship between the factors underlying the destination image and the empirical test of the impact of these destination image factors on domestic tourists revisit intention to BRVT. The research is done in two steps: qualitative and quantitative. The research results with a valid sample size of 398 domestic tourists showed that the scale was reliable, the value permissible, and study hypotheses are accepted, all eight destination image factors have positive effect on domestic tourists revisit intention to BRVT, according to the decreasing level of impact: Infrastructure $(\beta$ $=0.305)$, Variety Seeking $(\beta=0.228)$, Accessibility $(\beta$

$=0.176)$, Local food $(\beta=0.171)$, Atmosphere $(\beta=0.069)$, Environment $(\beta=0.047)$, Price Value $(\beta=0.042)$, Leisure and Entertainment $(\beta=0.022)$.

\subsection{Limitations of the Study}

This research has the following limitations: (1) Domestic tourists interviewed in this study come from different provinces, so it is possible to may have limited the representativeness of the overall population; (2) The process of interviewing is difficult due to the fact that the tourists do not want to spend time answering questions, so the quality of data is limited; (3) Other impact factors belong to domestic tourists revisit intention, but were not explored in the model. These limitations point the way for further studies.

\section{References}

Beerli, A., and Martin, J. (2004). Factors influencing destination image. Annals of Tourism Research, 31(3), 657-681.

Castro, C.B., Martin Armario, E. and Martin Ruiz, D. (2007). The influence of market heterogeneity on the relationship between a destinations image and tourists' future behavior. Tourism Management, 28(1), 175-187.

Chen, C.F., and Tsai, D.C. (2007). How destination image and evaluative factors affect behavioral intentions? Tourism management, 28(4), 1115-1122.

Chi, C.G. Q., and Qu, H. (2008). Examining the structural relationships of destination image, tourist satisfaction and destination loyalty: An integrated approach. Tourism management, 29(4), 624-636. 
Ha Nam Khanh GIAO, Nguyen Thi Kim NGAN, Nguyen Pham Hanh PHUC, Huynh Quoc TUAN, Ha Kim HONG, Huynh Diep Tram ANH, Duong Thi Huynh NHU7, Ngo Thi LAN / Journal of Asian Finance, Economics and Business Vol 7 No 6 (2020) 209 - 220

Crompton, J.L. (1979). An assessment of the image of Mexico as a vacation destination and the influence of geographical location upon that image. Journal of Travel Research, 17(4), 18-23.

Echtner, C.M., and Ritchie J.R.B. (2003). The Meaning and Measurement of Destination Image. Journal of Tourism Studies, 14, 37-48.

Giao, H.N.K. \& Bình, N.V. (2011). Giáo trình Nghiệp vu Nhà hàng. Nhà xuất bản Tổng hợp TPHCM. DOI: 10.31219/osf.io/hqjaf

Giao, H.N.K. \& Bình, N.V. (2014). Giáo trình Nghiệp vu Nhà hàng. Truờng Đại học Tài chính-Marketing. Nhà Xuất bản Thống kê. DOI: 10.31219/osf.io/r35jg

Giao, H.N.K. \& Hào, N.H. (2011). Đo lường chất lượng dịch vụ tại resort Whitesand. Tạp chí Nghiên cúu Tài chính-Marketing, 3, tháng 4-2011, 56-65. DOI: 10.31219/osf.io/57kdr

Giao, H.N.K. \& Sang, H.T. (2018). Các yếu tố thu hút khách du lịch nội địa đến huyện Côn Đảo, tỉnh Bà Rịa - Vũng Tàu. Tạp chí Công Thuơng, 15(tháng 12), 131-137. DOI: 10.31219/osf.io/gmxb3.

Giao, H.N.K. \& Son, L. T. (2012). Factors Affecting the Satisfaction of Visitors to Dalat Flower Festival 2012, Journal of Economic Development, 214(October), 144-156. DOI: 10.31219/osf.io/ p93ye

Giao, H.N.K. \& Son, L.T. (2014). Giáo trình Quản trị Chiến lược cho tổ chức $\mathrm{Du}$ lịch.. Nhà Xuất bản Thống kê. DOI: 10.31219/osf.io/tp9uv

Giao, H.N.K. \& Son, L.T. (2018). MICE tourism developmentExamination from the supply side in Dalat City, Vietnam. Global and Stochastic Analysis, 5(6), Special Issue 2018, 371 390. DOI: 10.31219/osf.io/r36yf.

Giao, H.N.K. \& Vuong, B.N. (2019). Giáo trình Cao hoc Phurong pháp Nghiên cúu Khoa học trong Kinh doanh- Cập nhật SmartPLS. Nhà xuất bản Tài chính. Hà Nội. DOI: 10.31219/osf.io/ hbj3k. ISBN: 978-604-79-2154-6

Giao, H.N.K. (2004). Marketing Dịch vụ-Mô hình 5 Khoảng cách Chất luợng Dịch vụ. Nhà Xuất bản Thống kê.

Giao, H.N.K. (2011). Giáo trình Marketing Du lịch. Nhà xuất bản Tổng hợp TPHCM. DOI: 10.31219/osf.io/z4yhd

Giao, H.N.K. (2011). Textbook Tourism Marketing. Ho Chi Minh City, Vietnam: HoChiMinh City General Publisher.

Giao, H.N.K. (2017). Customer Satisfaction and Quality of Vietnam Airline Domestic Services. International Journal of Quality Innovation, 3(1), 1-11, DOI 10.1186/s40887-017-0019-4, https://ideas.repec.org/a/spr/ijoqin/v3y2017i1d10.1186_ s40887-017-0019-4.html

Giao, H.N.K. (2018). Decision to purchase online airline tickets in Ho Chi Minh City, Vietnam. National Academy of Managerial Staff of Culture and Arts Herald, 4, 459-470. http://jrhnamsca. icu/index.php/hnamsca/issue/view/1. DOI: 10.31219/osf. io/fzh5v.
Giao, H.N.K. (2018). Sách chuyên khảo Đo luờng chất lượng dịch vu tại Việt Nam- nhì tù phía khách hàng. Nhà xuất bản Tài chính. Hà Nội. DOI: 10.31219/osf.io/cqh68. ISBN: 978- 60479-1788-4

Giao, H.N.K. (2018a). Decision to choose fast food restaurants of the young people in HCMC, Vietnam. National Academy of Managerial Staff of Culture and Arts Herald, 4, 471-485. http://jrhnamsca.icu/index.php/hnamsca/issue/view/1. DOI: $10.31219 /$ osf.io/xgv2k.

Giao, H.N.K. (2018b). Factors Influencing Customer Behavior of Butter Oil Substitute in Vietnam. Journal of Business and Economics, 9(3), 266-274, DOI: 10.15341/jbe(21557950)/03.09.2018/005. DOI: 10.31219/osf.io/gn6em

Giao, H.N.K. (2018c). Study of the Factors Affecting Customers' Loyalty for Gym Service at K.I.M Center, Vietnam. International Journal of Scientific Engineering and Research (IJSER), 6(12), 67-76. http://www.ijser.in/archives/v6i12/ IJSER18459.pdf. DOI: 10.31219/osf.io/57g8a.

Giao, H.N.K. (2018d). Vietnamese consumers' attitude on television advertisement of skin care. National Academy of Managerial Staff of Culture and Arts Herald, 4, 486-491. http://jrhnamsca.icu/index.php/hnamsca/issue/view/1 . DOI: $10.31219 /$ osf.io/a2bn9.

Giao, H.N.K. (2019a). Attidtude and Intention to buy VietGAP vegetables of inhabitants in HoChiMinh City. International Journal of Agricultural Economics, 4(3), 125-134. doi: 10.11648/j.ijae.20190403.16. file:///C:/Users/Prof.\%20 Giao/Downloads/10.11648.j.ijae.20190403.16.pdf

Giao, H.N.K. (2019b). Customer Satisfaction towards ATM Services: A Case of Vietcombank Vinh Long, Vietnam. Journal of Asian Finance, Economics and Business, 6(1), 141-148. http://doi.org/10.13106/jafeb.2019.vol6.no1.141

Giao, H.N.K. (2020). Customer Satisfaction at Tiki.vn E-Commerce Platform. Journal of Asian Finance, Economics and Business, 7(4), 173-183. https://doi.org/10.13106/jafeb.2020.vol7. no4.173

Giao, H.N.K., Bình, N.V. \& Tùng, N.S. (2014). Giáo trình Quản trị Kinh doanh Khách sạn. Truờng Đại học Tài chính-Marketing. Nhà Xuất bản Thống kê. DOI: 10.31219/osf.io/7ysem

Giao, H.N.K., Hoai, A.T., Vinh, P.Q. (2019). Quản trị Kinh doanh Dịch vụ-Tù Góc nhìn Marketing. Nhà xuất bản Truyền thông Thông tin Hà Nội. DOI: 10.31219/osf.io/98hrd. ISBN: 978604-80-3905-9

Giao, H.N.K., Hoan, N.C., Dung, T.Q., Vinh, N.L., Anh, L.T.L. (2014). Giáo trình Quản trị Kinh doanh Lũ hành. Nhà Xuất bản Thống kê. DOI: 10.31219/osf. io/87unw

Giao, H.N.K., Kiem, D., Son, L.T. \& Dung, T.Q. (2018). Satisfaction of tourists to Hoi An ancient town, Vietnam. Global and Stochastic Analysis, 5(8), Special Issue 2018, 123136. DOI:10.31219/osf.io/sbjev.

Giao, H.N.K., Phuc, N.P.H. \& Ngan, N.T.K. (2018). The affect of destination image factors on revisit intention of domestic 
tourists at Bà Rịa-Vũng Tàu. Global Conference on Business, Hospitality and Tourism Research (GLOSEARCH 2018), October 2-5, 2018 at the Hoa Sen University, Ho Chi Minh City, Vietnam, 143-157.

Giao, H.N.K., Trung, T. \& Truong, P.Q. (2019). Outbound service quality at Wan Hai Lines. Journal of Asian Finance, Economics and Business, 6(1), 177-185. http://doi.org/10.13106/ jafeb.2019.vol6.no1.177

Giao, H.N.K., Vuong, B.N. \& Quan, T.N. (2019). The influence of website quality on consumer's e-loyalty through the mediating role of e-trust, esatisfaction, and perceived enjoyment: An evidence from online shopping in Vietnam. Uncertain Supply Chain Management, 8(2), 351-370. DOI: 10.5267/j. uscm.2019.11.004.

Giao, H.N.K., Vuong, B.N., Huan, D.D., Tushar, H. \& Quan, T.N. (2020). The Effect of Emotional Intelligence on Turnover Intention and the Moderating Role of Perceived Organizational Support: Evidence from the Banking Industry of Vietnam. Sustainability, 12(5), 1857-1882. doi:10.3390/su12051857.

Huang, S., \& Hsu, C. H. (2009). Effects of travel motivation, past experience, perceived constraint, and attitude on revisit intention. Journal of Travel Research, 48(1), 29-44.

Huyen, L.H.B. \& Binh, L.T (2020). Impact of Destination Image and Satisfaction on Tourist Loyalty: Mountain Destinations in Thanh Hoa Province, Vietnam. Journal of Asian Finance, Economics and Business, 7(4), 185-195. https://doi. org/10.13106/jafeb.2020.vol7.no4.185

Kim, H., and Richardson, S. L. (2003). Motion picture impacts on destination images. Annals of Tourism Research, 30(1), 216237.

Kim, J. H. (2014). The antecedents of memorable tourism experiences: The development of a scale to measure thedestination attributes associated with memorable experiences. Tourism Management, 44, 34-45.

Lee, C. K. (2009). A structural model for examining how destination image and interpretation services affect future visitation behavior: a case study of Taomi eco-village. Journal of sustainable Tourism, 17(6), 727-745.

Loureiro, S.M.C., and Gonzalez, F.G.M. (2008). The Importance of Quality, Satisfaction, Trust, and Image in Relation to Rural Tourist Loyalty. Journal of Travel \& Tourism Marketing, 25(2), 117-136.

Medlik, S. and Middleton, V.T.C. (1973). Product Formulation in Tourism. In Tourism and Marketing, 13, 573-576.
Nhu, D.Q., Khang, N.T.N. \& Nhu, L/Q. (2013). Effects of destination image on Vietnam and international revisit intention. Science Magazines-Can Tho University, 27, 1-10.

Park, D.B., and Nunkoo, R. (2013). Relationship between Destination Image and Loyalty: Developing Cooperative Branding for Rural Destinations. Proceedings of the International Conference on International Trade and Investment (ICITI) - Non-Tariff Measures, the New Frontier of Trade Policy? University of Mauritius/WTO Chairs Programme, Le Meridien, Mauritius, 4th-6th September 2013. ISSN 169412225. (Refereed proceedings).

Phau, I., Quintal, V., \& Shanka, T. (2014). Examining a consumption values theory approach of young tourists toward destination choice intentions. International Journal of Culture, Tourism and Hospitality Research, 8(2), 125-139

Pike, S., \& Page, S. J. (2014). Destination Marketing Organizations and destination marketing: A narrative analysis of the literature. Tourism Management, 41, 202-227.

Rubies, E.B. (2001). Improving public-private sectors cooperation in tourism: a new paradigm for destinations. Tourism Review, 56(3/4), 38-41.

Son, L. T. \& Giao, H.N.K. (2018). The model of developing MICE in Vietnam from the resources factors. Vietnam Trade and Industry Review, 1(January), 234-239. DOI: 10.31219/osf.io/ u4bxw.

Svetlana, S., \& Juline E.M. (2010). Destination Image: A MetaAnalysis of 2000-2007 Research. Journal of Hospitality Marketing \& Management, 19(6), 575-609.

Truong, N.X. (2020). Factors That Influence the Intentions to Revisit Korea of Vietnamese Tourists. Journal of Asian Finance, Economics and Business, 7(4), 247-258. https://doi. org/10.13106/jafeb.2020.vol7.no4.247

Tuu, H.H \& Cam, T.T. A. (2012). Positive word of mouth and revisit intention of international visitors to Nha Tang City. Journal of Economic Development, 262, 55-61.

Vuong, B.N. \& Giao, H.N.K. (2019). The impact of brand globalness on consumers purchase intention and the moderating role of consumer ethnocentrism an eveidence from Vietnam. Journal of International Marketing, 32(1), 47-68. DOI: 10.1080/08961530.2019.1619115. https://www.tandfonline. com/doi/full/10.1080/08961530.2019.1619115.

Williams, C., \& Buswell, J. (2003). Service quality in leisure and tourism. UK: CABI Publishing. 